EASTERN REVIEW 2018, T. 7

Krzysztof Łabędź

\title{
Uwarunkowania lokalnej aktywności obywatelskiej
}

Problemy związane z niskim poziomem aktywności obywatelskiej (zaangażowania, partycypacji obywatelskiej) ${ }^{1}$ czy też konsekwencjami tego m.in. w postaci słabości społeczeństwa obywatelskiego (mówiąc dokładniej, istnieje i powstaje wiele organizacji społecznych, które jednak mają niewielkie zdolności mobilizacji do uczestnictwa) są częstym przedmiotem różnego rodzaju wypowiedzi. Wyjątkiem jest aktywność mająca charakter protestu, podejmowana w wyniku istniejących konfliktów, w formach określanych niekiedy jako niekonwencjonalne (bezpośredniego uczestnictwa). Odnosi się to również do skali lokalnej, kiedy nieformalne grupy mieszkańców protestują przeciwko różnym decyzjom dotyczącym przede wszystkim sposobu zagospodarowania przestrzeni danego miejsca.

Wśród prób wyjaśnienia niezadowalającego poziomu aktywności wymienić można m.in. stwierdzenia mówiące o niskim poziomie elit politycznych (dbających przede wszystkim o interesy swoje i swojej partii), co współtworzy sytuację bezalternatywności w demokratycznym systemie politycznym. Można także odwołać się do cech kultury politycznej społeczeństwa, w której jednocześnie występują przekonania podkreślające znaczenie współdziałania oraz zjawisko określane jako kultura nieufności. Ponadto można przyjąć, że aktywność jest wynikiem poczucia zagrożenia własnych interesów czy podstawowych odczuwanych wartości (wskazują na to m.in. teorie genezy ruchów społecznych, szczególnie te, które podkreślają obecność konfliktu), nie występuje w okresie, kiedy dominuje poczucie zadowolenia i bezpieczeństwa. Niektóre wyjaśnienia odwołują się przede wszystkim do właściwości psychiki czy charakteru ludzi, z których część ma cechy sprzyjające podejmowaniu aktywności, a inna część - sprzyjające bierności. Istnieją także inne możliwości tłumaczenia zarysowanej sytuacji, któ-

${ }^{1}$ Używany tu termin „aktywność” bywa używany zamiennie m.in. z „zaangażowaniem” oraz „uczestnictwem” lub „partycypacją”. Zob. K. Skarżyńska, Aktywność i bierność polityczna, [w:] Podstawy psychologii politycznej, red. K. Skarżyńska, Poznań 2002, s. 27. 
re łącznie są wyjaśnieniami cząstkowymi, komplementarnymi względem siebie, a dopiero zebrane w całość wyjaśnienie zbliżone do pełnego.

Poniżej, w odpowiedzi na pytanie, co wpływa na aktywność obywatelską podejmowaną w skali lokalnej, zostanie podjęta próba zestawienia i uszczegółowienia niektórych, uznanych przez autora za ważne, czynników. Chodzi przy tym o zasygnalizowanie wielości i złożoności tych uwarunkowań, które powodują, że w praktyce wyjaśnienie pełne byłoby niezwykle trudne, a działania podejmowane w celu zwiększenia partycypacji obywatelskiej nie przynoszą znaczących skutków. Najpierw jednak konieczne jest przybliżenie dwóch zagadnień - jak rozumiana będzie tutaj ,aktywność obywatelska” oraz dlaczego problem został przedstawiony w odniesieniu do skali lokalnej.

Termin „aktywność obywatelska” ma w założeniu dotyczyć węższego zakresu niż np. aktywność publiczna czy aktywność społeczna, ma również obejmować inne kwestie niż „społecznikostwo” (rozumiane jako działania na rzecz innych osób z najbliższego otoczenia, świadczenie pomocy sąsiedzkiej itp.). Określenie „obywatelska” ma wskazywać, że chodzi o zachowania ${ }^{2}$ związane z posiadaniem praw obywatelskich, czyli o znacznie szerszy zakres niż obejmowany zazwyczaj terminem ,aktywność polityczna”. Jest to aktywność związana zarówno z funkcjonowaniem systemu demokracji przedstawicielskiej (wybory samorządowe, kontakt z przedstawicielami), jak również realizowana w formach demokracji uczestniczącej (w tym deliberacji), do których należą m.in. referenda lokalne (odwoławcze lub przedmiotowe), obywatelska inicjatywa uchwałodawcza, budżet obywatelski, konsultacje społeczne i warsztaty obywatelskie, a także uczestnictwo w różnego rodzaju organizacjach. Warto dodać, że choć aktywność obywatelska może przejawiać się w działaniach podejmowanych indywidualnie, to szczególne znaczenie mają działania przedsiębrane wspólnie z innymi osobami (zarówno jeśli chodzi o realizację określonego celu, jak również w aspekcie tworzenia kapitału społecznego czy budowy tożsamości grupowej). Ważne jest także dodanie, że chodzi o aktywność przyczyniającą się do budowy społeczeństwa obywatelskiego, a zatem aktywność niesprzeczną z realizacją wartości o charakterze demokratycznym. Ograniczenie do aktywności podejmowanej w skali lokalnej wynika z przyjęcia kilku założeń: większej identyfikacji z miejscem zamieszkania $^{3}$, lepszego zrozumienia miejscowych uwarunkowań i rozpoznania potrzeb, potencjalnie lepszej wiedzy o istniejących możliwościach działania, wyraźniejszego związku pomiędzy własnym działaniem a jego skutkami, czyli większych możliwości wywierania wpływu na sprawy publiczne, lepszej znajomości osób,

\footnotetext{
${ }^{2}$ Obejmuje to zarówno podjęcie, jak też powstrzymanie się od określonych działań.

${ }^{3}$ Wskazują na to wyniki badań CBOS - zob. np. Małe ojczyzny - poczucie przynależności Polaków, Komunikat CBOS, BS/151/2009, www.cbos.pl (dostęp 13.10.2016); Co łaczy Polaków?, Komunikat CBOS, BS/168/2013, www.cbos.pl (dostęp 13.10.2016); Polacy o swoim przywiazaniu do miejsca zamieszkania i kraju, Komunikat CBOS nr 165/2015, www.cbos.com (dostęp 15.10.2016).
} 
z którymi podejmuje się współdziałanie. Łącznie powinno to sprzyjać relatywnie wysokiemu poziomowi aktywności, a jeśli tak nie jest, to należy zastanowić się dlaczego. Wiele poniżej sformułowanych uwag odnosi się jednak do aktywności obywatelskiej w ogóle, podejmowanej także w skali ponadlokalnej.

Dla egzemplifikacji istniejącego stanu w omawianym zakresie zostaną wykorzystane możliwie aktualne dane dotyczące społeczności Krakowa. Ma to dodatkowe znaczenie, gdyż społeczność ta charakteryzuje się w znacznej części cechami powszechnie uznawanymi za sprzyjające wyższej aktywności (wielkość miasta, poziom wykształcenia i dochodów, a ponadto charakter podstawowych funkcji, związanych z nauką, kulturą, turystyką itp.). Podstawą wysuwanych spostrzeżeń jest analiza danych przekazywanych przez miejskie portale internetowe (w tym BIP Urzędu Miasta) i lokalną prasę, a także wyniki badań ankietowych (przede wszystkim prowadzonych przez CBOS). Prócz tego, elementy teorii zostaną zaczerpnięte $\mathrm{z}$ literatury naukowej związanej z omawianymi zagadnieniami.

Istnieje wiele koncepcji, które można wykorzystać do określenia uwarunkowań aktywności publicznej (politycznej, obywatelskiej), a ich przedstawienie warto zacząć od wskazania pewnych prawidłowości o charakterze psychologicznym. Krystyna Skarżyńska, wychodząc z założeń teorii działania celowego, „zgodnie, z którą motywacja do podjęcia jakiegoś działania jest wypadkową subiektywnej wartości (użyteczności) przewidywanych wyników i subiektywnych oczekiwań dotyczących prawdopodobieństwa ich osiągnięcia”, stwierdza też: „Aby interes jakiejś społeczności (tak zwany interes wspólny) pobudził aktywność polityczną jednostki, musi stać się także jej subiektywnym interesem"4.

Znajduje to potwierdzenie w podejściu do wielu często deklarowanych wartości (m.in. rodziny, ojczyzny, religii), nie mówiąc już wartościach politycznych w rodzaju państwa czy demokracji, w którym dominuje pragmatyzm, a ich ocena uzależniona od tego, na ile wartości te zapewniają odpowiednio wysoką jakość życia danej jednostki. W tym kontekście poszczególne wartości mają charakter instrumentalny wobec dostatniego, zdrowego i szczęśliwego życia: ,u podstaw procesu wartościowania różnorakich dóbr u Polaków leży zindywidualizowany pragmatyzm, który staje się nadrzędną wartością wobec pozostałych"s. Na podstawie tej obserwacji (obecnej także m.in. u Marka Ziółkowskiego czy Janusza Czapińskiego) można stwierdzić, że należy oczekiwać, iż naczelną normą postępowania większości jednostek będzie podporządkowanie działań partykularnym interesom. A zatem będzie podejmowana przede wszystkim aktywność, z którą wiąże się oczekiwanie jakichś korzyści, np. zaspokojenia potrzeby wpływu czy afiliacji, uzyskania poczucia skuteczności czy po prostu osiągnięcia czegoś, czego nie osiągnie się będąc ,pasażerem na gapę”.

${ }^{4}$ K. Skarżyńska, Aktywność i bierność..., s. 41.

${ }^{5}$ E. Budzyńska, Podzielane czy dzielace? Wartości społeczeństwa polskiego, [w:] Wartości, postawy $i$ więzi moralne w zmieniajacym się społeczeństwie, red. J. Mariański, L. Smyczek, Kraków 2008, s. 46. 
Trzeba przy tym dodać, że możliwość udziału w demokratycznym życiu społecznopolitycznym znalazła się na ostatnim miejscu wśród wybieranych przez respondentów wartości (wybrana w 2013 r. przez 0,2\% badanych) ${ }^{6}$, czyli aktywność publiczna nie jest czymś cenionym, podobnie jak organizacje społeczne. Trwałe (po krótkim okresie w latach 1980-1981) okazało się zjawisko „próżni socjologicznej”, czyli sytuacji, w której żadne organizacje społeczne nie są traktowane jako wartościowe - brak poczucia więzi lub słabą więź z jakąkolwiek organizacją społeczną zadeklarowało $92 \%$ badanych, natomiast jedynie $2,7 \%$ identyfikowało się z jakąś organizacją społeczną?.

Aby przybliżyć uwarunkowania wpływające na poziom aktywności obywatelskiej, można wykorzystać zestawienie Piotra Sztompki, który wśród czterech rodzajów czynników decydujących o tym, czy mamy do czynienia ze społeczeństwem aktywnym (czyli zdolnym do samoprzekształcania się), wymienił: cechy jednostek, właściwości struktur społecznych, panujący w społeczeństwie stosunek do tradycji oraz wizję oczekiwanej przeszłości.Wymieniając cechy osobowościowe, stwierdził, że na społeczeństwo aktywne składają się jednostki twórcze, innowacyjne, zorientowane na osiągnięcia, cechujące się znaczną wiedzą, wyobraźnią i realizmem, mające poczucie autonomii, integralności i niezależności. Struktury społeczne, czyli warunki, w których ludzie podejmują działania, mają gwarantować swobodną, twórczą aktywność, to struktury pluralistyczne, heterogeniczne, otwarte, elastyczne, tolerancyjne wobec różnorodności i oryginalności. O stosunku do przeszłości decyduje to, że społeczeństwo aktywne jest zakorzenione w przeszłości, a własna tradycja jest przedmiotem dumy i szczególnej lojalności jego członków. W odniesieniu do przyszłości w aktywnym społeczeństwie panuje optymizm i nadzieja, poczucie mocy, przekonanie o własnej sile sprawczej, myślenie perspektywiczne i strategiczne, antycypowanie i planowanie w długiej perspektywie czasowej ${ }^{8}$.

Przedstawienie wszystkich wyżej zarysowanych zagadnień wymagałoby przeprowadzenia szeroko zakrojonych badań. Warto jednak wspomnieć, że we współczesnym społeczeństwie polskim występuje wiele przekonań mających dysfunkcjonalny charakter wobec zaistnienia społeczeństwa aktywnego zgodnego z charakterystyką P. Sztompki. Świadczą o tym wyniki badań stwierdzających wysoki poziom dogmatyzmu światopoglądowego (cechującego myślenie ok. 2/3 społeczeństwa ${ }^{9}$ ), wyraźny wzrost postaw ksenofobicznych (z 26,5 do 32,3\%), stwier-

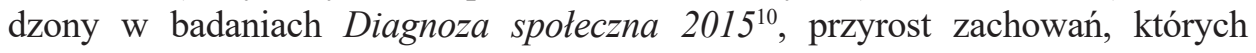

${ }^{6}$ Wartości i normy, Komunikat CBOS BS/111/2013, www.cbos.pl (dostęp 10.10.2016).

7 Więzi społeczne $i$ wzajemna pomoc, Komunikat CBOS, BS/24/2008, www.cbos.pl (dostęp 10.10.2016).

${ }^{8}$ P. Sztompka, Socjologia. Analiza społeczeństwa, Kraków 2002, s. 449-450.

9 Zob. I. Jakubowska-Branicka, Mentalność demokratyczna a dogmatyzm. Przemiany postaw społeczeństwa polskiego w procesie demokratyzacji, [w:] Wartości, postawy..., s. 129.

10 J. Czapiński, Stan społeczeństwa obywatelskiego, [w:] Diagnoza społeczna 2015, red. J. Czapiński, T. Panek, Warszawa 2015, s. 349-350, www.diagnoza.pl, 2015 (dostęp 15.10.2016). 
podłożem jest nienawiść etniczna czy rasowa, mowa nienawiści obecna w wielu wypowiedziach (szczególnie w Internecie), w tym także w wypowiedziach czołowych polityków, stosunek do przyjmowania uchodźców, hasła głoszone w trakcie licznych manifestacji (m.in. „Polska dla Polaków”, „Śmierć państwu islamskiemu” czy „Nie islamska, nie tęczowa, tylko Polska narodowa”). Dalekie od optymizmu są także nastroje społeczne, w których w zasadzie od początku pomiarów przeważa pesymizm - w 2016 r., na pytanie, czy sytuacja w Polsce zmierza w dobrym, czy złym kierunku, 37\% stwierdziło, że w dobrym, a 47\%, że w złym ${ }^{11}$.

Koncepcje uzasadniające aktywność lub jej brak, przedstawiane przez Piotra Sztompkę, związane są z podkreśleniem decydującej roli zaufania społecznego w funkcjonowaniu społeczeństwa, rozróżnieniem kultury zaufania i kultury nieufności, wprowadzeniem pojęcia więzi moralnej czy określeniem relacji moralnych kształtujących przestrzeń międzyludzką (do najważniejszych zalicza: zaufanie, lojalność, wzajemność, solidarność, szacunek i sprawiedliwość) ${ }^{12}$. Poziom zaufania do różnych podmiotów, będący podstawowym składnikiem kapitału społecznego (w rozumieniu Roberta Putnama), można uznać za jeden z decydujących czynników warunkujących podejmowanie aktywności indywidualnej, ale przede wszystkim we współpracy z innymi osobami.

Wiele argumentów przemawia za tym, że w społeczeństwie polskim mamy do czynienia z silnymi przejawami kultury nieufności (cynizmu), czyli rozpowszechnioną i uogólnioną podejrzliwością w stosunku do osób i instytucji, nakazującą nieustannie monitorować i kontrolować ich działania w obawie przed oszustwami, nadużyciami, kłamstwami, nierzetelnością, spiskami i konspiracją ${ }^{13}$. Przed wskazaniem niektórych ze wskaźników warto dodać, że zjawisko to może się obecnie pogłębiać, o ile potwierdzi się wniosek sformułowany przez badaczy włoskich, że aktywność na portalach społecznościowych wpływa na obniżenie poziomu zaufania (m.in. ze względu na budzącą niepokój różnorodność spotykanych tam poglądów, przejawy agresji, ksenofobii, język nienawiści, a także fakt, że partnerzy są anonimowi i niewidoczni) ${ }^{14}$.

Na pytanie, czy większości ludzi można ufać, twierdząco odpowiedziało w 2015 r. jedynie 15,2\% badanych, a 13\% wierzyło w dobre intencje innych lu$\mathrm{dzi}^{15}$. Podobne wyniki uzyskano $\mathrm{w}$ innych badaniach, przeprowadzonych $\mathrm{w}$ styczniu 2016 r. - większości ludzi można ufać - 23\%, w stosunkach z innymi trzeba być bardzo ostrożnym $-74 \%{ }^{16}$. W 2015 r. 78\% badanych zgodziło się także z opi-

${ }^{11}$ Nastroje społeczne we wrześniu, Komunikat CBOS nr 131/2016, www.cbos.pl (dostęp 25.10.2016).

12 P. Sztompka, Kapitat społeczny. Teoria przestrzeni międzyludzkiej, Kraków 2016, s. 150.

13 P. Sztompka, Socjologia..., s. 326.

${ }^{14}$ P. Sztompka, Kapitat..., s. 328.

15 J. Czapiński, Stan społeczeństwa..., s. 333-334.

${ }_{16}$ Zaufanie społeczne, Komunikat CBOS nr 18/2016, www.cbos.pl (dostęp 15.10.2016). 
nią, że jeżeli człowiek nie ma się na baczności, inni to wykorzystają, a $63 \%$ z poglądem, że tam, gdzie jedni zyskują, inni muszą zawsze coś tracić ${ }^{17}$.

Zdecydowana większość społeczeństwa ufa jedynie osobom z najbliższego otoczenia: najbliższej rodzinie, bliskim znajomym, dalszej rodzinie, sąsiadom ${ }^{18}$. Zaufaniem nie cieszy się zdecydowana większość polityków; jesienią 2016 r. jedynie dwoje (Andrzej Duda i Beata Szydło) uzyskało deklarację zaufania ze strony więcej niż połowy badanych. Niski jest także poziom zaufania do większości instytucji publicznych, szczególnie do związanych ze sprawowaniem władzy politycznej. Co prawda, wysoki poziom zaufania, jakim obdarzane są m.in. instytucje charytatywne, wojsko, Kościół czy policja (od 89 do 65\%), świadczy o braku uogólnionej normy nieufności wobec instytucji w ogóle (choć najprawdopodobniej nie dotyczy to instytucji politycznych), to jednak wobec szeregu ich przeważa nieufność. Największa nieufność jest deklarowana wobec partii politycznych, sejmu i senatu, rządu, gazet i telewizji (od 65 do $49 \%)^{19}$.

Ponieważ jednoznaczne stwierdzenie, że mamy do czynienia z kulturą nieufności, nie jest praktycznie możliwe (choćby dlatego, że jest to pojęcie złożone, zależne od doboru wskaźników, a ponadto jest to zmienna stopniowalna), zostaną tutaj zasygnalizowane jedynie pewne elementy składające się zdaniem P. Sztompki na kontekst sytuacyjny (strukturalny) wpływający na ukształtowanie się kultury zaufania lub nieufności. Składa się on z pięciu czynników:

- stabilności normatywnej (której przeciwieństwem jest anomia), istniejącej wtedy, kiedy normy prawne, moralne, zwyczajowe gwarantują m.in. sprawiedliwość, bezpieczeństwo socjalne, ochronę obywateli, prawa podmiotowe itp.;

- przejrzystości organizacji społecznej - budowa, racje istnienia, zasady działania, kompetencje, rezultaty są znane i zrozumiałe (przeciwieństwem jest niejasność i tajemniczość);

- trwałości porządku społecznego, która w oczywisty sposób nie występuje w sytuacji radykalnej zmiany społecznej;

- podporządkowania władzy regułom prawa (przeciwieństwem jest arbitralność i brak odpowiedzialności władzy) - obejmującego ograniczenie kompetencji, ramy proceduralne, nadzór i kontrolę nad urzędnikami, wieloinstancyjność i możliwość odwołania się od decyzji itp.;

- realizowania uprawnień i egzekwowania obowiązków (przeciwieństwem bezsilność obywateli i permisywność władzy), czemu służy istnienie i działanie niezależnych instytucji, do których można się odwołać dla ochrony zagrożonych uprawnień (sądy, trybunały), oraz instytucji wymuszających realizację obowiązków (prokuratura, policja) ${ }^{20}$.

17 Psychologiczne charakterystyki elektoratów partyjnych, Komunikat CBOS nr 138/2015, www.cbos.pl (dostęp 04.10.2016).

18 Spoleczeństwo obywatelskie w Polsce A.D. 2012, red. M. Grabowska, Warszawa 2012, s. 22.

19 Ibidem, s. 28-30.

${ }^{20}$ P. Sztompka, Socjologia..., s. 318-319. 
Przytoczonych zostanie kilka wskaźników świadczących o występowaniu wymienionych wyżej elementów. O tym, że anomia jest obecna w społeczeństwie polskim, można wnosić na podstawie wielu wskaźników, bezpośrednich i pośrednich. Pierwsze obejmują wyrażenie przez respondentów zgody z następującymi opiniami: coraz trudniej dopatrzeć się jakiegoś sensu w otaczającym nas świecie $-63 \%$; jedyne, czego można być obecnie pewnym, to tego, że niczego nie można być pewnym $-83 \%$; przy istnieniu tak wielu różnych idei, teorii i światopoglądów często już nie wiadomo, w co wierzyć $-64 \%{ }^{21}$. Na temat poczucia sprawiedliwości można wnosić, opierając się na badaniach przeprowadzonych w 2014 r., w których na pytanie, czy uważasz swoje zarobki za sprawiedliwe, uzyskano następujący rozkład odpowiedzi: zdecydowanie tak - 4\%, raczej tak - 34\%, raczej nie $-39 \%$, zdecydowanie nie - 23\%. Swoje zarobki jako niesprawiedliwe częściej oceniały kobiety, pracownicy szeregowi, mniej zarabiający, tacy, których zarobki uległy obniżeniu. Jako bardzo niepokojący można uznać fakt, że wśród osób zarabiających poniżej 2800 zł aż $84 \%$ uważało swoje wynagrodzenia za niesprawiedliwe ${ }^{22}$.

Również wyniki badań, w których porównywano wysokość zarobków różnych kategorii zawodowych postrzeganą przez respondentów z zarobkami postulowanymi przez nich, świadczą o negatywnej ocenie systemu wynagradzania. Zasadniczym wnioskiem z tych badań było stwierdzenie, że Polacy postulują zdecydowane zmniejszenie obecnego zróżnicowania dochodów. Zdaniem badanych, najwyższe postrzegane dochody (dyrektora dużego przedsiębiorstwa) stanowią 18-krotność najniższych (sprzątaczki), podczas gdy postulowana rozbieżność dopuszcza jedynie 7-krotność, a w zdecydowanej większości przypadków jest mniejsza niż 4-krotność. Wśród tych, którzy zdaniem badanych niezasłużenie zarabiają zbyt dużo, najczęściej wymieniano posłów, ministrów i burmistrzów, a wśród tych, którzy zarabiają zbyt mało, sprzedawców sklepowych, sprzątaczki, pielęgniarki i robotników niewykwalifikowanych ${ }^{23}$.

Jako wskaźnik pośredni można wykorzystać opinie na temat demokracji jako formy rządzenia, czyli poglądy dotyczące podstawowej zasady konstytuującej system polityczny, świadczące o sile jego legitymizacji. W roku 2015 odpowiedź, że demokracja ma przewagę nad wszystkimi innymi formami rządu, wybrało $29 \%$, ze zdaniem, że niekiedy rządy niedemokratyczne mogą być lepsze, zgodziło się $14 \%$, że nie ma znaczenia, czy rząd jest demokratyczny, czy nie - $17,2 \%$, demokrację za złą formę rządów uznało 4,7\%, a 35,2\% nie udzieliło odpowiedzi ${ }^{24}$. Wynika z tego, że normy demokratyczne nie są czymś ważnym dla większości

${ }^{21}$ Psychologiczne charakterystyki...

${ }^{22}$ Czy nasze wynagrodzenia sa sprawiedliwe?, www.wynagrodzenia.pl (dostęp 10.06.2015).

${ }^{23}$ Polacy o zarobkach różnych grup zawodowych, Komunikat CBOS BS/127/2013, www. cbos.pl (dostęp 10.06.2015).

${ }^{24}$ J. Czapiński, Stan społeczeństwa..., s. 322. 
społeczeństwa, co zresztą znajduje potwierdzenie w badaniach świadczących o występowaniu tendencji autorytarnych, odmowie niektórym ludziom i grupom prawa do szacunku czy też dążeniu do zaostrzenia kar dla przestępców łącznie $\mathrm{z}$ wprowadzeniem kary śmierci.

Powszechne jest przekonanie, że istniejące normy nie pozwalają uniknąć zjawisk o charakterze patologicznym, określanych niekiedy mianem negatywnego kapitału społecznego - korupcji, nepotyzmu itp. W społeczeństwie dominuje przekonanie o korupcji wśród wysokich urzędników państwowych i polityków, np. o tym, że obsadzają krewnych, znajomych i kolegów na intratnych stanowiskach, twierdzi $84 \%$, załatwiają dla nich kontrakty i zamówienia publiczne $-79 \%$, biorą łapówki za załatwienie sprawy $-72 \%{ }^{25}$.

Kolejnym z wyróżnionych składników kontekstu strukturalnego jest przejrzystość organizacji społecznej, a o zakresie jej postrzegania może świadczyć fakt, że 51\% respondentów zgodziło się z opinią, że to nie rząd nami rządzi; ci, co naprawdę nami sterują, nie są w ogóle znani ${ }^{26}$. Jeśli chodzi o inne przesłanki pozwalające ocenić zakres zrozumienia przez społeczeństwo zasad funkcjonowania organizacji społecznej, to przede wszystkim można odwołać się do badań zainteresowania kwestiami politycznymi i wiedzy o polityce, jako determinujących możliwości poznania i zrozumienia tej organizacji - można powiedzieć, że zarówno istniejący poziom zainteresowania (duże zainteresowanie polityką deklaruje zwykle ok. $10 \%$ badanych $^{27}$ ), jak i poziom wiedzy nie sprzyjają rozumieniu zasad funkcjonowania organizacji społecznej.

W odniesieniu do trwałości porządku społecznego można jedynie stwierdzić, że po okresie transformacji systemowej (radykalnej zmiany społecznej) nastąpiła pewna stabilizacja w większości sfer życia społecznego, natomiast zmiany zachodzące po objęciu władzy przez PiS najprawdopodobniej są przez wiele osób odbierane jako świadczące o nietrwałości istniejących rozwiązań. Odczucia takie mogą się pogłębiać wraz z kolejnymi planowanymi zmianami.

Następny czynnik dotyczy sposobu realizacji zasady państwa prawa, odpowiedzialności władzy, możliwości jej kontroli i odwoływania się od decyzji. W tym przypadku trudno znaleźć wyniki, które bezpośrednio świadczyłyby o postrzeganiu tych kwestii przez społeczeństwo. Po części odnoszą się do nich przytoczone wyniki badań dotyczących postrzegania patologii w życiu politycznym, a ponadto fakt, że obywatele mają bardzo niskie poczucie wpływu na sprawy kraju (deklarowane w 2015 r. przez 24\%, przy 73\% twierdzących, że wpływu nie mają), czyli na to, co robi rząd, choć poczucie wpływu na sprawy lokalne jest

${ }^{25}$ Polacy o nepotyzmie $w$ życiu publicznym, Komunikat CBOS, BS/124/2012, www.cbos.pl (dostęp 12.02.2016).

${ }^{26}$ Psychologiczne charakterystyki...

${ }^{27}$ Wskazują na to liczne badania TNS-OBOP, w których pytanie o zainteresowanie polityką jest zwykle zadawane. 
wyższe (w 2015 r. poczucie wpływu na sprawy swojego miasta lub gminy deklarowało $49 \%$, a jego brak $48 \%{ }^{28}$ ).

Ostatni czynnik kontekstu strukturalnego - możliwość realizowania uprawnień i egzekwowania obowiązków - związany jest przede wszystkim z treścią prawa, jego przestrzeganiem i sposobem funkcjonowania instytucji z tym związanych. Wyniki badań świadomości społecznej, które można odnieść do tego zakresu, skłaniają do stwierdzenia, że nie jest to czynnik przyczyniający się do budowy zaufania. Jeśli chodzi o ocenę prawa, to przeważa przekonanie, że problemem jest przede wszystkim złe, nieskuteczne egzekwowanie prawa (57\%), a nie treść norm prawnych (40\%). 76\% stwierdziło, że sankcje karne przewidziane przez prawo są zbyt łagodne, a 14\%, że wymierzane kary są nieadekwatne do popełnianych czynów. O stanie praworządności może świadczyć to, że 51\% stwierdziło, iż większość zwykłych ludzi w Polsce często nie przestrzega prawa (44\%, że Polacy zazwyczaj prawa przestrzegają) ${ }^{29}$. Działanie sądów źle oceniało $46 \%$ respondentów (dobrze tylko $29 \%$ ), a prokuratury $37 \%$ (dobrze $30 \%)^{30}$. Wedhug $84 \%$ badanych najważniejszym problemem jest przewlekłość postępowań sądowych, ponad 70\% wskazało także na notoryczne opóźnienia rozpraw, zbyt wysokie koszty sądowe oraz zbyt skomplikowane procedury. Na pytanie, czy sędziowie są niezawiśli, rozkład odpowiedzi był następujący: tak, zawsze $-4 \%$, tak, w zdecydowanej większości orzeczeń $-18 \%$, czasem tak, czasem nie $-44 \%$, nie $-22 \%{ }^{31}$.

Podsumowując, można powiedzieć, że wiele elementów kontekstu sytuacyjnego sprzyja istnieniu kultury nieufności, a zatem także niskiemu poziomowi aktywności. Aby wskazać uwarunkowania aktywności obywatelskiej, można przytoczyć także zestawienie czterech podstawowych czynników służących opisowi i diagnozie partycypacji społecznej w gminie, przedstawione przez Magdalenę Kalisiak-Mędelską. Należą do nich: postawa mieszkańców (stosunek do zaangażowania w procesy decyzyjne dotyczące spraw lokalnych) - aktywna lub bierna, postawa władz lokalnych (skłonność do włączania w proces decyzyjny innych uczestników życia publicznego, umiejętność wykorzystania ich wiedzy) - otwarta lub zamknięta, polityka informacyjna (informowanie mieszkańców o bieżących i planowanych działaniach, a także pozyskiwanie od nich informacji) - dwukierunkowa lub jednokierunkowa oraz klimat lokalny (uwarunkowania administracyjne, instytucjonalne, polityczne, społeczne) - sprzyjający lub niesprzyjający ${ }^{32}$.

${ }^{28} 25$ lat państwa obywatelskiego. Społeczne oceny samorządności terytorialnej, Komunikat CBOS nr 69/2015,www.cbos.pl (dostęp 25.10.2016).

${ }^{29}$ O przestrzeganiu prawa i funkcjonowaniu wymiaru sprawiedliwości w Polsce, Komunikat CBOS, BS/5/2013, www.cbos.com.pl (dostęp 15.10.2016).

${ }^{30}$ Oceny instytucji publicznych, Komunikat CBOS nr 43/2016, www.cbos.com.pl (dostęp 20.10.2016).

${ }^{31}$ O przestrzeganiu prawa...

${ }^{32}$ M. Kalisiak-Mędelska, Partycypacja spoteczna na poziomie lokalnym jako wymiar decentralizacji administracji publicznej w Polsce, Łódź 2015, s. 277. 
$\mathrm{Na}$ ich podstawie wśród uwarunkowań aktywności można podjąć refleksję dotyczącą działania władz lokalnych, a wśród składników lokalnego klimatu poruszyć m.in. kwestię sposobu działania organizacji pozarządowych, liczby i autorytetu liderów lokalnych, a także np. nasilenia konfliktów.

Postawa władz lokalnych oraz urzędników reprezentujących instytucje administracji samorządowej może w różny sposób wpływać na poziom aktywności. W części działania władz zmierzające do włączenia mieszkańców do procesów decyzyjnych mają charakter pozorny. Znalazło to odzwierciedlenie w drabinie partycypacji przedstawionej przez Sherry R. Arstein, która wyróżniła osiem typów partycypacji, z których dwa to brak uczestnictwa (manipulacja, terapia), kolejne trzy to działania pozorne (informowanie, konsultacje, ugłaskiwanie), a jedynie trzy oznaczają uspołecznienie władzy (partnerstwo, delegowanie, kontrola obywatelska) $)^{33}$.

Dobrych praktycznych przykładów błędów popełnianych przede wszystkim przez urzędników samorządowych, ale także przez polityków działających na szczeblu lokalnym, związanych z korzystaniem z procedur demokracji partycypacyjnej, dostarczają niektóre działania podejmowane w Krakowie w ostatnich latach.

Najbardziej widoczną formą partycypacji lokalnej jest budżet obywatelski. W pierwszej edycji budżetu obywatelskiego w 2014 r. (wcześniej próbe przeprowadzono w kilku dzielnicach) zgłoszono 656 (499 dzielnicowych i 157 miejskich, z których do głosowania dopuszczono 462) projektów, udział w głosowaniu wzięło ok. 10\% mieszkańców (w wieku co najmniej 16. lat), a do wykorzystania było 4,5 mln zł, w tym 1,8 na projekty dzielnicowe. W roku 2015 suma do rozdysponowania wyniosła ok. $14 \mathrm{mln}(10 \mathrm{mln}$ na przedsięwzięcia ogólnomiejskie i 4 mln na dzielnicowe), zgłoszono 611 pomysłów, z których władze odrzuciły ponad 150 . Frekwencja była jednak mniejsza i wyniosła 7,5\%, co dało argument za zmniejszeniem sumy budżetu obywatelskiego w $2016 \mathrm{r}$. do $8,5 \mathrm{mln}$ zł na projekty ogólnomiejskie i $2 \mathrm{mln} 355$ tys. na dzielnicowe. W 2016 r. (401 projektów: 122 ogólnomiejskie i 279 dzielnicowych) frekwencja była jeszcze niższa (7\%), a zdaniem Michała Malczyńskiego z portalu Krowoderska.pl przyczyną jest to, że: „Projekty, które wygrywały lata temu, albo nie zostały zrealizowane, albo ich realizacja pozostawia wiele do życzenia" ${ }^{34}$.

Wprowadzenie w Krakowie budżetu obywatelskiego od razu uwidoczniło szereg problemów, które można podzielić na trzy grupy: stosunkowo niewielkie zainteresowanie mieszkańców, trudności wynikające z działania władz i admini-

33 S.R. Arnstein, Drabina partycypacji, [w:] Partycypacja. Przewodnik krytyki politycznej, Warszawa 2012, s. 16.

${ }^{34}$ Budzet obywatelski 2016, http://www.radiokrakow.pl/wiadomosci/krakow/budzet-obywatelski-2016najwiecej-glosow-na-szkolenia-szybowcowe-park-w-czyzynach-i-wodny-plac-zabaw-w-parku-jordana/ (dostęp 25.10.2016). 
stracji samorządowej oraz niewielka skala realizacji wybranych projektów. Jeden z problemów należących do pierwszej grupy wskazywano w ewaluacji pierwszej edycji: „Za słabość etapu wypracowywania dokumentu należy uznać mały udział mieszkańców w tym procesie. Co prawda, spotkania Zespołu były otwarte dla wszystkich, ale uczestniczyli w nich głównie radni, przedstawiciele UMK oraz instytucji i organizacji pozarządowych zajmujących się kwestiami związanymi z zarządzaniem miastem" "35. Ta sama słabość uwidoczniła się w trakcie spotkań konsultacyjnych (76 dzielnicowych i jedno ogólnomiejskie, w których łącznie uczestniczyło ok. 1,1 tys. osób), a wśród przyczyn absencji podawano kolejno brak czasu, wiedzy oraz zainteresowania. W dodatku (to należy już do drugiej grupy) uczestniczący w spotkaniach radni dzielnicowi często nie mieli odpowiedniej wiedzy oraz zdarzało się, że „radni publicznie »recenzowali« pomysły mieszkańców i/lub »agitowali« na rzecz innych, co w powiązaniu z faktem zgłaszania przez nich własnych projektów budziło wątpliwości uczestników co do uczciwości całego procesu" ${ }^{36}$. Istotną wadą było również słabe zarysowanie funkcji deliberacyjnej spotkań. Jest to zresztą słabością wynikającą z całej przyjętej procedury, która ma charakter bardziej konfliktogenny niż konsensualny. Wiele wątpliwości budziło ponadto działanie urzędników już po złożeniu wniosków - zbyt późne informowanie o potrzebie uzupełnienia projektu (pod koniec czerwca, gdy wielu studentów już wyjechało na wakacje), utrudnianie składania odwołań od decyzji urzędników, naruszanie regulaminu budżetu obywatelskiego.

Problemów z pierwszej grupy nie oddaje do końca ilość zgłoszonych projektów, a być może także liczba głosujących. Już w pierwszej edycji okazało się, że autorami części zgłoszonych projektów są osoby prowadzące działalność polityczną oraz radni. Projekt miejski, który uzyskał w 2014 r. największą liczbę głosów, został zgłoszony przez działaczy młodzieżówki PO. Można również sądzić, to radni inspirowali wiele projektów zgłaszanych przez kogoś innego. Ponadto rok później wykryto próbę oddania kilkuset głosów przy użyciu programu komputerowego, o co podejrzewano radnego, autora projektu, na który te głosy były oddane. W celu zaktywizowania mieszkańców, lepszego ich poinformowania w poszczególnych dzielnicach organizowane były spotkania informacyjne, konsultacje i warsztaty mające pomóc przy tworzeniu własnego projektu, ale zainteresowanie nimi było słabe. Przykładem może być zebranie dotyczące projektu nowego regulaminu budżetu obywatelskiego na 2016 r., w którym wzięło udział ok. 10 osób, a serwis internetowy „Dialog Społeczny” odwiedziło w trakcie konsultacji tego projektu 1154 osoby.

W roku 2016 wyraźnie uwidocznił się jeszcze inny problem - w głosowaniu wygrał projekt przewidujący zakup trzech szybowców w celu przeszkolenia szy-

${ }^{35}$ Ewaluacja pierwszej edycji Budżetu Obywatelskiego w Krakowie, Warszawa-Kraków 2014, s. 10, www.krakow.pl/zalacznik/207941 (dostęp 12.01.2016).

${ }^{36}$ Ibidem, s. 35. 
bowcowego 30 osób oraz sfinansowania bezpłatnych lotów wycieczkowych dla 200 osób (za ponad 1,5 mln zł), projekt, który najprawdopodobniej nie powinien być poddany pod głosowanie, bo dotyczy korzyści dla jedynie niewielkiej liczby osób. Prócz tego okazało się, że przy małej liczbie głosujących zwycięstwo można zapewnić, „kupując głosy”, czym zajmują się wyspecjalizowane firmy (podobno za 215 głosów płacono ankieterom 1 tys. zł). Ponadto $12 \%$ głosów było nieważnych, a zawiódł system komputerowy (była to jedyna możliwość głosowania). Trzecia edycja budżetu obywatelskiego w Krakowie dowiodła więc, że procedura ta może służyć, wbrew założeniom, realizacji partykularnych interesów niewielkich grup ${ }^{37}$.

W Krakowie miała miejsce także próba doprowadzenia do referendum odwołującego urzędującego prezydenta. Inicjatorem był jego kontrkandydat w wyborach prezydenckich oraz potencjalny kandydat na to stanowisko, założyciel stowarzyszenia monitorującego działania prezydenta. Okazało się jednak, że podpisy pod wnioskiem o referendum, za które inicjator płacił po 2 zł, w większości zostały zebrane nieprawidłowo. Spośród 87242 osób, których podpisy złożył, 38919 osób nieprawidłowo udzieliło poparcia, a aż 21288 osób nie miało praw wyborczych na terenie gminy Kraków. Można to uznać za kompromitację znanego polityka (byłego posła), ale przy okazji także za czynnik zniechęcający do podejmowania aktywności obywatelskiej ${ }^{38}$.

Funkcjonowanie organizacji pozarządowych (utożsamianych z trzecim sektorem) coraz częściej spotyka się z krytyką. Wśród argumentów pojawiają się m.in. następujące stwierdzenia: NGO-sy zamiast budować aktywne społeczeństwo wyręczają obywateli, nie są ruchami społecznymi, ale kolejnymi uczestnikami systemu sprawowania władzy, często realizują cele przewidziane dla administracji publicznej, pozyskiwanie i sprawna realizacja grantów staje się dla nich celem samym w sobie, działają od grantu do grantu, dostosowując działania do możliwości zdobycia środków, tracąc $\mathrm{z}$ pola widzenia początkowe cele ${ }^{39}$. W związku z taką oceną pojawiają się stwierdzenia, że NGO-sy cierpią na „grantozę”, „urządowienie”, „komercjalizację" itp. ${ }^{40}$ Niemniej jednak to przede wszystkim te organizacje uczestniczą w konsultacjach społecznych (w 2015 i 2016 r. w ponad połowie konsultacji ogłoszonych przez władze miejskie Krakowa - łącznie było to 50 projektów - prawo uczestnictwa miały wyłącznie organizacje wymienione w ustawie z 2003 r. o organizacjach pożytku publicznego i wolontariacie) i często nie zgłaszają żadnych uwag do przedstawianych projektów.

${ }^{37}$ Kraków kupi trzy szybowce, http://www.gazetakrakowska.pl/wiadomosci/krakow/a/miasto-kupi-trzyszybowce-dla-230-lotow-za-15-mln-zl-sami-urzednicy-sa-w-szoku,10372614/ (dostęp 25.10.2016).

${ }^{38}$ Oficjalnie: nie będzie referendum w Krakowie, http://www.gazetakrakowska.pl/ wiadomosci/krakow/a/oficjalnie-nie-bedzie-referendum-w-krakowie,10500657/ (dostęp 25.10.2016).

${ }^{39}$ Zob. np. B. Martela, Aktywność obywatelska w ramach inicjatyw nieformalnych. Przyczynek do refleksji, „Acta Universitatis Lodziensis. Folia Sociologica” 2011, nr 38.

${ }^{40}$ Zob. np. J. Sowa, Wyschnięte źródło? O ewentualnych pożytkach i aktywności społeczeństwa obywatelskiego, „Animacja Życia Publicznego” 2015, nr 1, s. 15, www.cal.org.pl (dostęp 30.04.2016). 
Kończąc wymienianie czynników, które wpływają na aktywność obywatelską, nie można pominąc roli lokalnych liderów. Jak wskazują liczne przykłady, grupy osób podejmujących jakąś wspólną aktywność tworzą się wokół nich - osób mających zdolność mobilizacji innych do działania, a nawet mobilizacji w miarę masowych ruchów społecznych. Jednostek takich jest jednak stosunkowo niewiele, a ich pojawienie się można określić jako przypadkowe. W badaniach prowadzonych w latach 90. stwierdziliśmy, że w krakowskiej dzielnicy charakteryzującej się relatywnie sporym poziomem aktywności mieszkańców znaczną rolę jako inicjator i katalizator aktywności odegrał proboszcz miejscowej parafii, w jednej ze wsi podkrakowskich był to sołtys, ale skupione wokół nich grupy miały charakter ściśle enklawowy. Wydaje się, że podobnie w Krakowie jest obecnie - można wskazać kilka osób skupiających wokół siebie i mobilizujących do działania spore grupy mieszkańców (najczęściej osoby te inicjują wiele działań) oraz pewną liczbę aktywistów działających w sposób mniej spektakularny, mających już znacznie mniejsze możliwości mobilizacji.W tym przypadku można stwierdzić, że środowisko lokalne ułatwia znajomość i podjęcie kontaktu, choć rolę nie do przecenienia odgrywa obecnie Internet - wszystkie właściwie inicjatywy lokalne, obejmujące nie tylko najbliższych sąsiadów, zawiązały się dzięki komunikacji sieciowej.

Powyżej wymienione zostały jedynie niektóre uwarunkowania aktywności, z których część można odnieść przede wszystkim do aktywności lokalnej. Pominięto wiele innych, np. poziom zadowolenia $\mathrm{z}$ istniejącej sytuacji, poziom zaspokojenia potrzeb mieszkańców przez wyspecjalizowane instytucje (w zakresie infrastruktury, estetyki otoczenia, spędzania czasu wolnego itd.), tradycje rodzinne, tradycje lokalne, ilość posiadanego czasu wolnego czy też szereg zmiennych położenia społecznego oraz wiele różnych postaw i przekonań. Względnie pełna analiza uwarunkowań aktywności obywatelskiej wymagałaby przeprowadzenia szeroko zakrojonych, interdyscyplinarnych badań, uwzględniających bardzo wiele zmiennych, a zatem wymagających odniesienia do dużej liczebnie próby społeczeństwa. Wydaje jednak, że nawet takie badania, ze względu na złożoność problemu oraz zróżnicowanie i zmienność przedmiotu badań, nie doprowadziłyby do sformułowania jednoznacznych wniosków.

\section{Bibliografia}

25 lat państwa obywatelskiego. Społeczne oceny samorządności terytorialnej, Komunikat CBOS nr 69/2015, www.cbos.com.pl (dostęp 25.10.2016).

Arnstein S.R., Drabina partycypacji, [w:] Partycypacja. Przewodnik krytyki politycznej, Warszawa 2012.

Budzyńska E., Podzielane czy dzielace? Wartości społeczeństwa polskiego, [w:] Wartości, postawy $i$ więzi moralne $w$ zmieniajacym się społeczeństwie, red. J. Mariański, L. Smyczek, Kraków 2008. 
Budżet obywatelski 2016, http://www.radiokrakow.pl/wiadomosci/krakow/budzet-obywatelski-2016najwiecej-glosow-na-szkolenia-szybowcowe-park-w-czyzynach-i-wodny-plac-zabaw-w-parku-jordana/ (dostęp 25.10.2016).

Co łaczy Polaków?, Komunikat CBOS, BS/168/2013, www.cbos.pl (dostęp 13.10.2016).

Czapiński J., Stan społeczeństwa obywatelskiego, [w:] Diagnoza społeczna 2015, red. J. Czapiński, T. Panek, Warszawa 2015, s. 349-350, www.diagnoza.pl (dostęp 15.10.2016).

Czy nasze wynagrodzenia sa sprawiedliwe?, www.wynagrodzenia.pl (dostęp 10.06.2015).

Ewaluacja pierwszej edycji Budżetu Obywatelskiego w Krakowie, Warszawa-Kraków 2014, s. 10, www.krakow.pl/zalacznik/207941 (dostęp 12.01.2016).

Jakubowska-Branicka I., Mentalność demokratyczna a dogmatyzm. Przemiany postaw spoteczeństwa polskiego w procesie demokratyzacji, [w:] Wartości, postawy i więzi moralne w zmieniajacym się społeczeństwie, red. J. Mariański, L. Smyczek, Kraków 2008.

Kalisiak-Mędelska M., Partycypacja społeczna na poziomie lokalnym jako wymiar decentralizacji administracji publicznej w Polsce, Łódź 2015.

Kraków kupi trzy szybowce, http://www.gazetakrakowska.pl/wiadomosci/krakow/a/ miasto-kupi-trzyszybowce-dla-230-lotow-za-15-mln-zl-sami-urzednicy-sa-w-szoku,10372614/ (dostęp 25.10.2016).

Małe ojczyzny - poczucie przynależności Polaków, Komunikat CBOS, BS/151/2009, www.cbos.pl (dostęp 13.10.2016).

Martela B., Aktywność obywatelska w ramach inicjatyw nieformalnych. Przyczynek do refleksji, „Acta Universitasis Lodziensis. Folia Socjologica” 2011, nr 38.

Nastroje społeczne we wrześniu, Komunikat CBOS nr 131/2016, www.cbos.pl (dostęp 25.10.2016).

O przestrzeganiu prawa i funkcjonowaniu wymiaru sprawiedliwości w Polsce, Komunikat CBOS, BS/5/2013, www.cbos.com.pl (dostęp 15.10.2016).

Oceny instytucji publicznych, Komunikat CBOS nr 43/2016, www.cbos.com.pl (dostęp 20.10.2016).

Oficjalnie: nie będzie referendum w Krakowie, http://www.gazetakrakowska.pl/ wiadomosci/ krakow/a/oficjalnie-nie-bedzie-referendum-w-krakowie,10500657/ (dostęp 25.10.2016).

Polacy o nepotyzmie w życiu publicznym, Komunikat CBOS, BS /124/2012, www.cbos. $\mathrm{pl}$ (dostęp 12.02.2016).

Polacy o swoim przywiazaniu do miejsca zamieszkania i kraju, Komunikat CBOS nr 165/2015, www.cbos.com (dostęp 15.10.2016).

Polacy o zarobkach różnych grup zawodowych, Komunikat CBOS BS/127/2013, www. cbos.pl (dostęp 10.06.2015).

Psychologiczne charakterystyki elektoratów partyjnych, Komunikat CBOS nr 138/2015, www.cbos.pl (dostęp 4.10.2016).

Skarżyńska K., Aktywność i bierność polityczna, [w:] Podstawy psychologii politycznej, red. K. Skarżyńska, Poznań 2002.

Sowa J., Wyschnięte źródło? O ewentualnych pożytkach $i$ aktywności społeczeństwa obywatelskiego, „Animacja Życia Publicznego” 2015, nr 1, s. 15, www.cal.org.pl (dostęp 30.04.2016).

Społeczeństwo obywatelskie w Polsce A.D. 2012, red. M. Grabowska, Warszawa 2012.

Sztompka P., Kapitat społeczny. Teoria przestrzeni międzyludzkiej, Kraków 2016.

Sztompka P., Socjologia. Analiza społeczeństwa, Kraków 2002.

Wartości i normy, Komunikat CBOS BS/111/2013, www.cbos.pl (dostęp 10.10.2016). 
Więzi społeczne $i$ wzajemna pomoc, Komunikat CBOS, BS/24/2008, www.cbos.pl (dostęp 10.10.2016).

Zaufanie społeczne, Komunikat CBOS nr 18/2016, www.cbos.pl (dostęp 15.10.2016).

\section{Krzysztof Łabędź}

\section{Обусловленность локальной гражданской активности}

В тексте предпринята попытка определения некоторых факторов, являющихся причиной того, что гражданская активность в польском обществе находится на относительно низком уровне, что также имеет место на региональном уровне, который должен в свою очередь эту активность повышать. Основываясь на некоторых, присутствующих в предметной литературе концепциях, в статье представлены избранные факторы, объясняющие актуальное положение дел. Особое внимание уделено определенным закономерностям психологического характера, избранным взглядам и поведениям общества, затрудняющим партиципацию, с особенным уклоном на те из них, которые влияют на возникновение культуры недоверия, а также на неточности и ошибки, осуществляемые в процессе использования форм партиципационной демократии (на примере Кракова).

Ключевые слова: гражданская активность, культура недоверия, формы партиципационной демократии, взгляды польского общества.

Krzysztof Łabędź

\section{Determinants of local civic engagement}

The paper is an attempt to indicate some conditions causing that civic activity in Polish society is at a relatively low level, even on a local scale, which should promote high activity. Such a situation can be explained by selected factors basing on some concepts in the scientific literature. Firstly, attention was paid to certain psychological norms, selected views and attitudes of the society that may make it difficult to undertake any activities. There are some factors that lead to a culture of distrust as well as shortcomings and mistakes made when using forms of participatory democracy (on the example of Cracow).

Keywords: civic engagement, culture of mistrust, forms of participatory democracy, views of the Polish society. 